\title{
Activity proposal for the improvement of transversal competence "Knowledge of contemporary problems" in a university subject
}

\author{
Vicente Guerola-Navarro $^{a}$, Raúl Oltra-Badenes ${ }^{\mathrm{a}}$, Hermenegildo Gil-Gomez ${ }^{\mathrm{a}}$ \\ ${ }^{a}$ Departamento de Organización de Empresas. Universitat Politècnica de València (SPAIN).
}

\begin{abstract}
The sole proprietorship enterprise, in its legal form of Autonomous Worker, is one of the most frequent and important today. Both for its tax obligations, as for the specific functional and management characteristics, as well as for its relevance in the services sector, it is interesting for the students to know and to assess their details and peculiarities.

In the planning guide of very few subjects the special characteristics of this business model are detailed, so we think it is interesting to dedicate a practical session to know how different the management of an Autonomous Worker is from that of the rest of corporate legal forms.

We sincerely believe that this practical session could improve the learning of the transversal competence "Knowledge of Contemporary Problems" by the students. We also believe that this will be a very interesting experience that will familiarize students with a business reality that they will undoubtedly find in the near future.

We propose that the most appropriate format for this teaching activity is that of Active Learning, since it implies a greater active participation of students, with the expectation therefore of better learning outcomes. In this specific case, we propose that an Autonomous Worker, with some academic training in management and administration, attends to the practical session with the students of the subject, and a practical workshop is held in which simulate different aspects of working life and Business of an Autonomous Worker.

The result of this activity proposal, and its greatest novelty with respect to other teaching courses, is the proposal of 7 concrete and specific blocks to work with students in "group dynamics" format, as well as the presence of an experienced external speaker with academic training enough, so that students effectively reach the development of the skill that this competence proposes. With that, students are expected to get actively involved and to learn what the professional life of this type of business model is.
\end{abstract}


Keywords: Knowledge of contemporary problems, Transversal competence; Active Learning; Student outcomes.

\section{Introduction}

The reality of the Enterprise is one of the most complex in the current economic model, not only because of its economic characteristics, but also because of the implications that the social, economic, geopolitical and cultural environment have on creation, development and function Corporate Social (De Castro et al., 1996). That is why in the Universities, not only the reality of the Company is studied in the University Degrees focused on Economics and Finance, but it is also a core point of study in Degrees with a more technological focus, since the professional activity of Engineers, Architects, and other technical professionals, will be conditioned and directed in large part by this business reality.

The structure, processes and models of the different types of companies currently existing in the market is a dynamic reality that allows the company to evolve along with the reality of the environment in which it develops its business activity (Bueno Campos, 2007) . All this determines that the activity of the company is developed within the modern and dynamic field of economy of the company that defines Castro (2014) as one of the richest, changing, evolutionary, and challenging of recent times.

Since the subject in which the academic proposal of this paper is intended to be carried out, it is developed in Engineering, it is of crucial importance to consider, together with the economic and organizational concept of the Enterprise, also and in an additional and essential way the concept and environment of the industrial economy (Durbán et al., 2010). The administration and management of an industrial company, object of intensive and extensive study by the Degree in Business Administration and Management, is one of the most complex and challenging areas of study for professionals who both in the economicfinancial area and in the technical-functional area develop their activity (Robbins and Mary, 2005). Business concepts and strategies are therefore the most key areas of knowledge to successfully develop any activity of high responsibility within the company (Santesmases, 1999).

"Enterprise" is one of the core subjects of almost all the Degrees in Engineering that are taught at the Polytechnic University of Valencia, specifically in Mechanical Engineering and Electrical Engineering. The subject is taught in different courses of said Degrees in Engineering, depending on which one it is. In all the Degrees in which this subject is studied, the main objective of the subject is to provide the student with a complete and general vision of what the company concept encompasses. Likewise, it is intended to arouse 
the interest of the future graduate in Electrical Engineering in a field in which it will have to be developed during his professional activity. The final objective of the subject is to introduce the student to the basic concepts of Enterprise reality, so that the student can reach the theoretical-practical basic knowledge for knowing how to value the impact that the enterprise structure and organization may affect the company's future and success (Ochoa, 1996).

In addition to the expected outcomes related to the complex and global reality of the Enterprise, this subject has additional outcomes called "transversal", meaning that during the acquisition of fundamental concepts by the student, the student must also acquire certain competencies not directly related to enterprise structures and models, but also with the student's own development as a person and professional, and also their transversal competences (Menguzzato and Renau, 2007). To achieve these competencies, training activities should be carried out, based on active methods of learning skills and student participation methods that generate a deeper, meaningful and sustainable learning, all driven under the concept of Active Learning (March, 2006).

Looking at the present requirements for successful professionals in this subject area, one of the most important transversal skills to be developed by the student should be "Knowledge of Contemporary Problems", which refers to how to Identify and interpret contemporary problems in their field of specialization, as well as in other fields of knowledge, paying special attention to aspects related to sustainability (March, 2006). This competence refers to the need for students to understand contemporary political, social, legal and environmental issues and values, as well as the mechanisms for expanding and disseminating knowledge. It is about developing the ability to "keep up" with current events in their field of knowledge and in society in general. In order to work on this competence, training scenarios must be sought in which students discuss this type of questions in depth, being able to summarize the most relevant aspects and defend a position on it. Similarly, it is very important that they learn to evaluate complex situations using different approaches, such as: economic aspects, quality of life, environmental impacts, local and national policies.

\section{1.- The Subject "Enterprise" and its competencies.}

In the subject "Enterprise" the business economic environment, the market and competitiveness are studied. The concept of Business as a socio-economic reality and the figure of entrepreneur and his managerial function are also analyzed. In addition, the structure of the company is analyzed as an organization, forms and classes of companies; size, concentration and growth of the company. 
Finally, the operation of the company, the management system and business decisions are studied, as well as the following functional areas of the company: the technical system, functional analysis and investment, the financing system, the operations system, information and the marketing or marketing system. The focus of the subject is intended to be eminently practical, so the different theoretical concepts are analyzed with cases and practical examples of business reality.

Having said previously that the main objective of the subject is to provide the student with a complete and general vision of what the company concept encompasses, the content of the subject is structured in these basic topics:

- Introduction:

a. Fundamentals of business economics

b. Company and environment

- Business Management

a. The managerial function

b. Business planning and strategy

c. Structure and design of the organization

- The functions of the company

a. Commercial address

b. Production of goods and services

c. Financial management

In "Enterprise" subject the following competences are worked on, empowering their development through Active Learning methodology during the course:

- Ability to organize and plan at the company level, and other institutions and organizations

- Ability to apply the principles and methods of quality

- Adequate knowledge of the company concept, institutional and legal framework of the company. Organization and business management

Besides, the student must learn to develop a series of transversal competencies (Universitat Politècnica de València, 2012) that will help the student to empower in a more effective way the basic competences (ICE, 2015), and that will not only be key for this subject but for all his / her personal and professional development:

- Innovation, creativity and entrepreneurship (04)

- Planning and time management (12) 
Our proposal regarding this subject is that, since the business world is increasingly dynamic and changing, a new transversal competence should be introduced as a key one, in this case known as the "Knowledge of Contemporary Problems" transversal competence, which should allow students know the reality of the different existing business models through training actions that, following the Active Learning methodology, introduce the student fully into the day-to-day reality of these business models. In this particular case, and as beginning enterprise model for study, our proposal is to analyze the reality of the "sole proprietorship enterprise", also known in Spain as "Autónomo".

\section{2.- The sole proprietorship enterprise.}

The sole proprietorship enterprise is one of the most traditional and extended enterprise model existing in Spain, our geographical study area.

In Spain, a self-employed worker (as it is also known the sole proprietorship enterprise) is the natural person who performs in a habitual, personal and direct way, an economic activity on a lucrative basis, without being subject to an employment contract, and even if he eventually uses the paid service of other people. The status of self-employed worker is presupposed, if the ownership of an establishment open to the public is held as owner, usufructuary, lessee or other similar concepts. The condition of self-employed worker is also presupposed, if the person is a teleworker who has clients and who performs a paid activity (despite working from home), and if he issues formal invoices for his activities since he is the owner of a sole proprietorship. The responsibility of the self-employed person is unlimited, responding to the business activities with all their present and future assets, so that there is no separation between personal assets and that of the company. In Spain, the main regulation of the autonomous worker regime is Law 20/2007, of July 11 (BOE, 2007).

In Spain there is traditionally fluctuation around 3 million self-employed workers. The figure is true, but it requires nuances: at the end of December 2018, there were around 3.2 million registrations in the Special Scheme for Autonomous Workers, also known as "RETA" (INE, 2018). Within a population of 19 million people employed in the Spanish labor market, the quantity of 3.2 million self-employed workers represents $20 \%$ of the employed population, and is therefore sufficiently representative of itself and important within the Spanish labor and business market to take it into account and devote efforts to its study and value. That's why we have decided to put special focus in this kind of sole proprietorship enterprise as the first sample model for implementing the new Knowledge of Contemporary Problems transversal competence in the Enterprise subject. 


\section{2.- Methodology}

In this section we present the two key points for our academical proposal:

- The leading speaker and its professional profile

- The Active Learning methodology

\section{1.- The leading speaker professional profile.}

We believe that the presence of an external speaker, outside the university community, with sufficient experience in the subject under study, can provide extra motivation and interest on the part of students, by breaking the routine and establishing new rules of the game within the University classroom.

The requirements that the rapporteur must meet are basically:

- have enough self-employed experience in a sole proprietorship enterprise

- have theoretical and practical knowledge about how a company of the type of sole proprietorship enterprise is managed and directed

- have sufficient capacity to propose group dynamics, lead them, and direct them to students to obtain their own conclusions (with the help of the teaching professor of the subject).

An example of a model speaker for this proposal of teaching activity would be a person with studies in the Degree of Business Administration and Management, or in the Business Administration Module, which currently and for at least 5 years has been exercising as a self- employee in a sole proprietorship enterprise. This would cover the desired duality between the specific work experience in this business model along with the convenience of having studies related to the subject.

Work experience in this type of company is considered important because in past activities of its own it has been shown that student interest grows when the speaker talks about their own experiences and not about documented academic theories but referenced in the third person.

It is also considered appropriate to possess academic knowledge in Business Administration and Management, because it has also been found in previous teaching activities of the authors that students value in a fair measure that the speaker has at least the basic knowledge that they are they are required in the academic development of their learning. 


\section{2.- The Active Learning methodology.}

In the search for better results and greater motivation of students and teachers, active learning is demonstrating its effectiveness, conceived as a learning methodology where the active participation of students in each and every one of the phases, stages and activities It is rewarded and encouraged. It is about motivating the students to participate actively and within a global plan so that the set of activities has a sense of set, so that the learning is really effective. The objective is to leave the students a post that will last after their academic stage, instead of the traditional objective of passing the subjects. It is, in short, to reinforce the goal of real learning. With this, students become protagonists of their own learning, instead of passive recipients of information (Konopka et al., 2015).

Araújo et al. (2014) is committed to the power of active learning methodologies, applied in modern and dynamic teaching environments, together with the personal and professional skills of the participants, as the most powerful tools to learn effectively. Along the same lines defines active learning Konopka et al. (2015): "the process of acquiring knowledge, skills, values and attitudes for any educational strategy that involves or involves students in the process by taking them to activities and debates, instead of simply putting them in the position of passively listening to information taught by the teacher ".

Ponsa et al. (2009) established a general framework in which to use active methodologies in higher education, establishing the phases of the project and the expected results. March (2006) argues that the use of active methodologies for learning and the evaluation of transversal competencies in higher education is presented as the most effective option to promote the personal and professional development of the student, since in them the responsibility of learning depends directly from your activity, participation and commitment. It is thus ensured that, with Active Learning methods, deeper learning is pursued more effectively.

\section{3.- Description of the practical lesson.}

The training activity has been designed with the aim of capturing the attention of the students on the particularities of the self-employee business in a sole proprietorship enterprise, so that they participate in a joint group dynamic with the speaker and the teacher in the classroom .

The first step should be to make a formal presentation of the speaker, so that it is clear both his academic qualification and his personal worth as an experienced professional in the business model under study. That is why it is suggested that the rapporteur, by his own means, and with visual support (digital presentation) projected in public, make a brief but complete introduction about his academic training (suggested as in some cases related to 
the administration and direction of companies), to go on to describe the basic details about your current professional activity as a self-employee.

After the formal presentation of the speaker and his professional activity, it is suggested to establish a sufficient number of group dynamics (sufficient and dependent on the duration of the training activity) in which the students face real usual situations of the day of a selfemployee in a sole proprietorship enterprise, and discuss what would be the most effective and reasonable way of acting (always based on the knowledge acquired in the subject). These group dynamics must be previously arranged between the speaker and the teacher of the subject, so as to ensure their consistency with the syllabus of the subject and the general and particular learning objectives of the subject according to their teaching guide.

The basic dynamics proposed in this study are:

- I have a small capital collected after a job dismissal from my previous employment, and I have knowledge and experience in a certain professional activity typically self-employed. What considerations do I have to take into account to face the decision to exercise (or not) as a self-entrepreneur?

- I have skills and knowledge to develop a professional activity as a selfentrepreneur, but do I know what are the formal and tax requirements and obligations of this business model? Which are?

- Today is Sunday night, and tomorrow begins a new week in which to develop my professional activity as a self-opera. What worries me? What have I taken into account and what have I forgotten?

- We live in a globalized world where information is accessible by customers, and markets are global, so any bidder can be contacted and required for a transaction by any customer regardless of place of residence or form of contact. Am I prepared for this type of digitalized and global business environment?

- I have a great capacity for work, and great skills to develop a certain professional activity, but do I know the space-time dedication required of a self-opera by the market? Do I know under what conditions (schedules, quality requirements, benefits, etc.) will I have to face the services to my potential clients? Is that acceptable to me and my personal situation?

- I already work as a self-entrepreneur in a professional activity recognized and appreciated by the market and my regular clients. What factors does a selfemployee value in this stable situation in order to expand (with possibly an employee) and diversify activities (in terms of type of activity to be exercised, and in terms of geographical area where to exercise it)? 
- If I had to choose, at different stages of my life (the rapporteur and the teacher define them during the activity) between working for someone else or being selfemployed, what would be the criteria I would use?

Given each of these dynamics, raised separately and led by the rapporteur, it is proposed that students offer their views and are discussed in the Classroom, waiting for the debate to have entered into reasonable time and content for the rapporteur to contrast student ratings with their own experience. For this purpose, the use of templates is recommended in which a person responsible for dynamizing the activity (usually the teacher) write down the opinions of the students, and the assessment of the speaker according to their experience, making it clear that all opinions are reasonable and that the experience of the rapporteur is one more whose value is that of who making certain decisions has reached success in his professional experience.

\section{3.- Results}

The expected results of this training activity proposal are the finding that the use of Active Learning methodologies are the most effective to definitely involve the student in their effective learning. It is therefore intended that, motivating the student to participate and be the protagonist of their own learning, they will obtain and retain in a lasting way the basic knowledge and skills that can make them a successful professional in the future.

One of the basic tools that are considered most effective in Active Learning are group dynamics, in which students, based on the knowledge acquired in the subject and in the rest of their academic career, participate actively exposing their opinions, without clippers or limits, in brainstorming format. From these group discussions, moderated by a dynamizer (typically the teacher) and introduced and put into context by an experienced professional in the area, students are expected to put themselves in a position to "live" their own experience virtually and consequently propose and decide active actions and positions. This type of debate and participation, we hope that (as confirmed in other activities in the line of Active Learning) is confirmed as effective in our particular proposal.

The fact that we have chosen that our Active Learning proposal be applied to the development of the Knowledge of Contemporary Problems competence, we trust that it will make our activity proposal more valuable, since it translates the student to a present reality and with great impact on the society (as we have seen, and in our case of self-opera in a sole proprietorship enterprise, at least $20 \%$ of the Spanish productive fabric). 
We hope to obtain as a result an effective learning about the knowledge of one of the most important realities of the market in which we live, through the development of a new competence in a subject of great impact in the future training of Degrees students in Engineering.

\section{4.- Conclusions}

After relating the benefits of Active Learning, with the basic and transverse competences of the "Enterprise" subject present in the Engineering Degrees, a possible area of improvement has been detected in terms of a skill that we consider relevant in the current situation, as is the one that reflects the transversal competence of Knowledge of Contemporary Problems.

We believe that the teaching guide of the subject, together with the general framework of the syllabus and current approach of the Degrees in which the subject is taught, justifies the proposal to carry out some training activity such as the one we propose to develop this transversal competence, using for this the methodologies that have the most impact on the current higher education system: Active Learning methodologies.

The development of this competence is also considered to be accompanied by an approach and a relevant and current environment, so the participation of an experienced external speaker with sufficient knowledge to launch and coordinate group dynamics has been proposed. based on technical and formal knowledge according to the higher educational level of the University in Degrees in Engineering.

The general conclusion of our proposal is that with this training activity students would probably gain a new key skill for their present and future development as professionals.

\section{References}

Araújo, U. F., Fruchter, R., Garbin, M. C., Pascoalino, L. N., \& Arantes, V. (2014). The reorganization of time, space, and relationships in school with the use of active learning methodologies and collaborative tools. ETD: Educaçao Temática Digital, 16(1), 84-99

BOE - Boletín oficial del Estado. Ley 20/2007. Madrid, España, 11 de Julio de 2007. BOE núm 13409. Obtained from: https://www.boe.es/buscar/doc.php?id=BOE-A-2007-13409

Bueno Campos, E. (2007). Organización de empresas: estructura, procesos y modelos (No. Sirsi) i9788436820942).

Castro, C. B. (2014). Economía de la empresa. Ediciones Pirámide. 
De Castro, Emilio Díez, José Luis Galán González, and Enrique Martín Armario. Introducción a la economía de la empresa. Pirámide, 1996.

Durbán Oliva, S., Ferrell, O. C., Mochón Morcillo, F., Baixauli Baixauli, J. J., Hirt, G. A., Trujillo Ruiz, F. de B., ... Ferrell, Linda. (2010). Empresa y economía industrial. Aravaca (Madrid): McGraw-Hill/Interamericana de España.

ICE - Instituto de Ciencias de la Educación. Universitat Politècnica de València. Proyecto $\begin{array}{lllll}\text { Competencias Transversales } & \text { UPV. } & \text { 2015. } & \text { Retrieved }\end{array}$ http://www.upv.es/entidades/ICE/info/U0724624.pdf

INE - Instituto Nacional de Estadística. Informe de Mercado Laboral, 2018. Obtained from: https://www.ine.es/dyngs/INEbase/es/categoria.htm?c=Estadistica_P\&cid=1254735976595

Konopka, C. L., Adaime, M. B., \& Mosele, P. H. (2015). Active teaching and learning methodologies: some considerations. Creative Education, 6(14), 1536

March, A. F. (2006). Metodologías activas para la formación de competencias. Educatio siglo XXI, 24, 35-56.

Menguzzato, M., \& Renau, J. J. (2007). La dirección estratégica de la empresa. Un enfoque innovador del management. Editorial Félix Varela.

Ochoa Laburu, Carlos. Economía y organización de empresas. San Sebastián: Donostiarra, 1996.

Ponsa, P., Amante, B., Román, J. A., Oliver, S., Díaz, M., \& Vives-Gràcia, J. (2009). Higher education challenges: introduction of active methodologies in engineering curricula. International Journal of Engineering Education, 25(4), 799-813

Robbins Stephen, P., \& Mary, C. (2005). Administración. Editorial Pearson, edición, 8.

Santesmases Mestre, M. (1999). Marketing: conceptos y estrategias. Pirámide,

Universitat Politècnica de València. Competencias transversales. 2012. Retrieved from http://www.upv.es/contenidos/COMPTRAN/info/956832normalc.html 